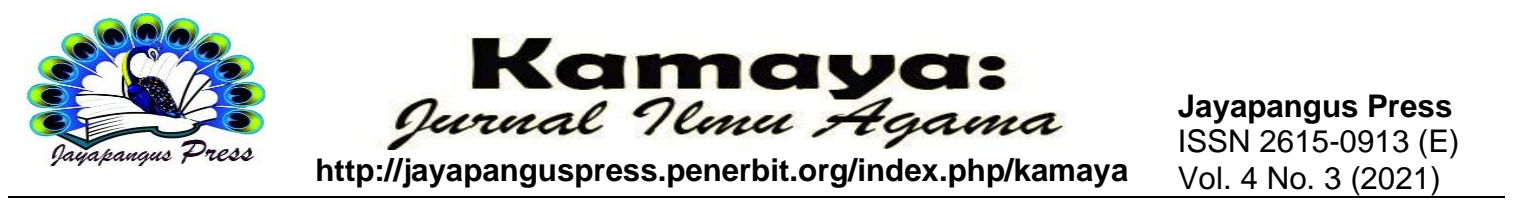

\title{
Ongkara Pranava Sebuah Konsep Ritual Dalam Diri
}

\author{
Ni Made Evi Kurnia Dewi \\ STAHN Mpu Kuturan Singaraja \\ nimdevikurniadewi@gmail.com
}

\begin{tabular}{l}
\hline Keywords: \\
\hline Ongkara \\
Pranava, Mantra \\
\hline
\end{tabular}

\begin{abstract}
This paper contains about Ongkara Pranava, the concept of ritual within the self. Ongkara Pranava is a sacred mantra that many Hindus chant in the archipelago, and even in the world. Another name for Ongkara is Pranava, which means "born of Prana". Prana is another name for breath, more precisely, breath is the grossest aspect of Prana, every breath that enters and leaves through human breathing is Ongkara. The human body is Ongkara. Breathing is an activity to cultivate the noble qualities within, to grow the Supreme consciousness and to become Consciousness itself. Accustomed to managing and practicing mindfulness through Ongkara meditation, the mantra itself can act as a map and at the same time a vehicle to run the boat of human self-awareness from the swift and complex currents of human thought, crossing the tidal waves originating from the currents of our own thoughts to improve quality. self and lead human consciousness to the Supreme consciousness. Ongkara Pranava, the concept of ritual within is studied using a qualitative descriptive method, the data collection technique used is a document study or literature study, then the data that has been collected will be analyzed descriptively qualitatively to obtain related conclusions about Ongkara Pranava, the concept of ritual within.
\end{abstract}

Kata Kunci:

Ongkara

Pranava, Mantra

\begin{abstract}
Abstrak
Tulisan ini memuat tentang Ongkara Pranava, konsep ritual dalam diri. Ongkara Pranava adalah mantram sakral yang banyak lantunkan oleh umat Hindu di nusantara, dan bahkan di dunia. Nama lain dari Ongkara adalah Pranava, yang artinya "terlahir dari Prana". Prana adalah sebutan lain dari nafas, lebih tepatnya, nafas adalah aspek Prana yang paling kasar, setiap nafas yang masuk dan keluar melalui pernafasan manusia merupakan Ongkara. Tubuh manusia merupakan Ongkara. Bernafas merupakan suatu aktifitas untuk menumbuhkan sifat-sifat mulia di dalam diri, menumbuhkan kesadaran Agung dan menjadi Kesadaran itu sendiri. Terbiasa mengelola dan melatih kesadaran melalui meditasi Ongkara, maka mantra itu sendiri dapat berperan sebagai peta dan
\end{abstract}


sekaligus kendaraan untuk menjalankan perahu kesadraan diri manusia dari deras dan kompleksnya arus pemikiran manusia, melintasi gelombang pasang surut yang bersumber dari arus gejolak pikiran kita sendiri menuju pada perbaikan kwalitas diri dan mengantarkan kesadaran manusia menuju pada kesadaran Agung. Ongkara Pranava, konsep ritual dalam diri ini dikaji menggunakan metode deskriptif kualitatif, Teknik pengumpulan data yang digunakan adalah studi dokumen atau studi pustaka, kemudian data yang telah terkumpul akan dianalisis secara deskriptif kualitatif untuk mendapatkan kesimpulan terkait tentang Ongkara Pranava, konsep ritual dalam diri.

\section{Pendahuluan}

Ongkara Pranava adalah mantram sakral yang paling banyak disenandungkan oleh umat Hindu di nusantara, dan bahkan di dunia. Om juga dipergunakan pada awal setiap sapaan yang dianggap dan bersifat sakral, seperti Om Sai Ram, Hari Om, Om Swastyastu, Om Santih, Santih, Santih, Om dan banyak lagi yang lainnya, bahkan pelafalan mantra dalam setiap kegiatan ritual di Bali selalu diawali dengan penyebutan kata Om. Realitasnya, suku kata suci Ong atau Om itu memiliki posisi yang maha penting, sebab semua mantra tanpa diawali Ongkara, maka mantra apapun tidak punya kekuatan dasyat. Tetapi, ketika Ongkara itu diucapkan menyertai sebuah mantra, maka mantra itu otomatis akan memiliki power kekuatan yang sangat dasyat luar biasa. Ongkara merupakan simbolisasi dari wujud Hyang Maha Esa, simbol Ongkara ini juga menyiratkan seluruh jagad raya yang hadir di dalam Hyang Maha Esa atau Siwa, itu sendiri.

Siwa memiliki dua sifat, Niskala dan Sekala, yang memiliki sifat-sifat niskala disebut Sunya Siwa, atau Siwa yang bersifat sunya yang dinamakan sebagai Sang Hyang Acintya. Ia tidak bisa di gambarkan, berada diluar jangkauan pemikiran manusia, karena sifatnya yang Nirguna, Ia tidak dapat dipikirkan dengan pikiran. Ia tidak bisa dikatakan dengan kata-kata. Ia tidak bisa dirasakan dengan indria perasa. Ia tidak bisa ditunjukkan dengan jari telunjuk. Siwa dalam hal ini bersifat niraksara. Ia tidak bisa direpresentasikan oleh aksara. Ia bebas dari aksara. Pengertiannya, ia melampaui aksara, karena tidak memiliki wujud sastra, maka sangat sulit sekali untuk dibayangkan, karena berada diluar jangkauan pemikiran manusia.

Yudiantara (2019:174) menjelaskan bahwa ketika Sang Kesadaran Agung menumbuh menjadi Kesadaran Personal. Sakti merupakan daya kreatif-dinamisnya 
sebagai faktor penting dalam proses penumbuhan tersebut. Dinamika Sakti yang pertama adalah sebagai sabda, ia menjadi "suara", menjadi vibrasi (Nada). Vibrasi tertentu memikili frekuensi berbeda, dan sabda dengan frekuensi berbeda ini kemudian menumbuh menjadi aksara. Demikian jika proses Sang Kesadaran Agung dilihat dengan simbolik aksara.

Pernyataan tersebut menegaskan bahwa ketika Siva yang tanpa rupa sebagai wujudnya Sang Kesadara Agung menumbuh menjadi kesadaran personal, sifat niskala berubah menjadi sifat sakala, maka Sakti sebagai daya kreatif Siva menjadi faktor penentu dalam wujudnya sebagai energi termaterialisasi menjadi aksara. Wujud material sekala dari Siva sebagai Ongkara adalah tubuh, seluruh tubuh dari makhluk hidup di alam semesta ini, kemudian Iapun menjadi isi dari Prana. Prana adalah wujud lain dari nafas, maka dapat dikatakan bahwa nafas merupakan aspek Prana yang paling kasar. Itulah sebabnya secara umum Pranava diartikan sebagai Ongkara yang ada di dalam tubuh.

Aktivitas bernapas terjadi begitu saja dan sering kali tidak disadari oleh kebanyakan orang. Bagaimana kita bergerak, berpikir, bertindak dan terutama bernafas sangat mempengaruhi vitalitas dari Prana, energi universal yang mengalir melalui diri kita dan ada di sekitar kita. Nafas sangatlah penting, karena nafas merupakan suatu hal yang pertama dan terakhir kali kita lakukan dalam hidup kita, karena semua manusia di muka bumi ini bernafas, tanpa nafas maka tidak akan ada lagi suatu kehidupan.

Istilah Pranava memiliki berbagai macam arti diantaranya: (1) pranuyate, yang berarti Diri tertinggi yang dipuja oleh semuanya, (2) Pranam avati, yang berarti pelindung energi vital, dan (3) prakarsena navikaroti, yang berarti pembaharu jiwa, yang membuat jiwa murnia sebagaimana adanya. Pranava yang umunya dikenal adalah (1) vedic Pranava, yaitu Pranava dalam bahsa Veda, berbunyi Aum, (2) Saiva Pranava, berbunyi Hum, dan (3) Sakta Pranava, berbunyi Hrim. Pranava adalah inti mantra yang menjadi dasar segala mantra. Vedic Pranava yang berbunyi Aum dilafalkan berulang-ulang sehingga menghasilkan energi yang luar biasa. Dalam svacchanda tantra dijelaskan secara terperinci bagaimana Pranava dapat menghasilkan energi yang dahsyat. Pranava juga sangat erat kaitannya dengan energi kehidupan (Prana) dan kebangkitan kundalini (Singh, 2017:18).

Prana merupakan energi kehidupan yang sangat dibutuhkan oleh seluruh makhluk hidup di alam semesta ini. Prana dalam kaitannya dengan Ongkara Pranava 
sangat memegang peranan yang cukup penting dalam mengarungi beragam pengalaman kehidupan manusia di alam semesta ini. Ongkara Pranava merupakan representasi dari diri manusia itu sendiri sebagai tubuh fisik maupun mental manusia. Ongkara Pranava merupakan salah satu media untuk mewujudkan keharmonisan hidup manusia bahkan Ongkara Pranava merupakan peta sekaligus kendaraan dalam ritual pribadi dalam diri setiap manusia.

\section{Metode}

Hasil tulisan dalam penelitian ini merupakan hasil penelitian kualitatif. Bogdan dan Tailor menyatakan penelitian kualitatif sebagai prosedur penelitian yang menghasilkan data deskriptif berupa kata-kata tertulis atau lisan dari orang-orang dan perilaku yang dapat diamati (dalam Moleong, 2001:3).

Penelitian kualitatif yang digunakan dalam tulisan ini dengan pertimbangan penelitian yang bersifat deskritif yang menekankan pada konsep Ongkara Pranava sehingga mendapat data yang lebih akurat. Teknik pengumpulan data yang peneliti gunakan, studi dokumen atau Studi Pustaka, hal ini perlu untuk dilakukan dengan cara membaca dan mencatat berbagai literatur yang terkait dan berhubungan dengan penelitian yang dikaji. Data yang telah terkumpul kemudian akan dianalisis secara deskriptif kualitatif untuk mendapatkan kesimpulan umum tentang Ongkara Pranava sebuah konsep ritual dalam diri.

\section{Hasil dan Pembahasan}

\section{Ongkara Pranava sebagai wujud Harmonisasi}

Ongkara Pranava merupakan wujud dari sebuah keharmonisan antara pikiran, tubuh fisik dan tubuh mental manusia dalam menjalani aktifitas kehidupan sehari-hari di dunia ini. Om atau Ongkara adalah sebuah beja (biji) mantra utama yang merupakan ucapan suku kata yang dianggap sangat suci dalam Agama Hindu. Ongkara merupakan aksara yang dipakai dalam kehidupan masyarkat Hindu di Bali sebagai simbol untuk melambangkan Ida Sang Hyang Widhi Wasa. Ongkara adalah sabda (suara) Brahman. Ketika sabda menjadi suara, ia akan menjadi vibrasi nada. Vibrasi tertentu memiliki frekuensi yang berbeda-beda, dengan frekuensi yang berbeda ini kemudian menumbuh menjadi aksara. 
Dalam pandangan Tantra, tubuh merupakan aksara yang telah mewujud menjadi nyata, menjadi fisik. Serupa dengan pandangan fisikal quantum bahwa materi (benda padat) tidak lebih merupakan energi dengan frekuensi tertentu yang telah termaterialisasi. Namun secara esensi, semua adalah Sakti. Artinya semua adalah shabda; semua adalah aksara (Yudiantara, 2019:174).

Esensinya energi merupakan bentuk dari seluruh yang ada di alam semesta ini, energi telah mewakili banyak hal dari wujud yang bersifat material dan non material di alam semesta, termasuk didalamnya Bhuana Aguang (alam semesta) dan Bhuana Alit (Manusia). Semua benda materi di alam semesta ini merupakan energi yang sudah termaterialisasi, namun jika dilihat dari tataran energi dalam tingkataan rendah, bahwa energi merupakan sebuah tenaga yang mampu membuat manusia menghasilkan gerak tubuh dalam menjalani kehidupannya sehari-hari, jika semua energi merupakan perwujudan dari Sakti, dan ketika Sakti menjadi shabda, menjadi suara, kemudian dengan frekuensi tertentu sabda menjadi aksara, maka energi adalah Sakti, Sakti adalah $s a b d a$, dan $s b d a$ adalah aksara, maka Energi yang telah termaterialisasi dalam sebuah wujud tertentu di alam semesta ini salah satunya adalah tubuh manusia sebagai wujud Bhuana alit, maka dapat dikatakan bahwa tubuh manusia itu sendiri merupakan wujud dari aksara, yaitu aksara Ongkara, seperti yang dijelaskan dalam Yudiantara (2019:3839) bahwa Lapisan tubuh terluar adalah raga-tubuh fisik. Lapisan terluar tubuh fisik yang bisa kita dan orang lihat secara kasat mata adalah Ongkara. Dada adalah Okara, bahu adalah ardhacandra, kepala adalah windu dan jalinan rambut adalah Nada. Kemudian organ-organ di dalam, yang tidak bisa lagi dilihat dengan mata telanjang tanpa bantuan alat-alat medis, juga adalah Ongkara. Singkatnya, Ongkara adalah seluruh raga, luar dan dalam. Tubuh fisik dibangun oleh elemen-elemen yang lebih halus, elemen dasar pembentuk semesta yang disebut pancamahabhuta (lima elemen utama). Pancamahabhuta tersebut pun adalah Ongkara. Sebutannya adalah Ongkarapancarengga, yaitu Ongkara sebagai pretiwi, apah, teja, bayu, akasa. Kelima elemen ini bukan hanya menjadi dasar pembentuk tubuh, namun juga pembentuk alam. Artinya, selain tubuh personal, Ongkara juga adalah tubuh semesta. Tentu saja, sebagaimana disebutkan dalam teks Ganapati tattwa, alam dan tubuh tidaklah berbeda.

Secara fisik tubuh banyak mengalami beragam pengalaman-pengalaman dalam kehidupan, pengalaman tersebut dapat dialami melalui pengalaman indrawi seperti pengalaman melihat melalui mata, mendengar melalui telinga, merasakan melalui 
indera kulit, indera pengecap mengalami pengalaman melalui lidah dan yang lainnya. Tubuh manusia hidup karena adanya roh atau jiwa yang menjiwainya, sedangkan tubuh fisik ini mengalami pengalaman materialnya di alam semesta ini karena ada yang menjiwainya berupa nafas, dengan bernafas seseorang telah belajar untuk menyalurkan dan menyeimbangkan energi kehidupan di dalam tubuhnya. Beragam pengalaman dalam kehidupan dapat dilakukan melalui proses bernafas. Secara esensi Ongkara dalam Bhuana Alit ini adalah Tubuh manusia, Ia berwujud sebagai Tubuh Fisik dari manusia, maka Pranawa dalam hal ini adalah Prana atau nafas yang menjiwai hidup manusia dalam menjalani pengalaman-pengalaman hidupnya di dunia ini, jadi Ongkara Pranava merupakan Ongkara di dalam Tubuh, wujud kasar dan nyata yang dapat dirasakan oleh manusia dari Ongkara Pranava adalah nafas.

Yudiantara (2019:40) kembali menegaskan Roh dari tubuh fisik adalah nafas. Saat bernafas, ada udara masuk, ada udara keluar. Keduanya adalah aspek lain dari Ongkarabhineda, yaitu Ongkara-Ngadeg dan Ongkara-Sungsang, yang personifikasi lainnya adalah aksara Rwabhineda ANG-AH. Keduanya juga adalah suara nafas masuk dan nafas keluar. Nama lain dari Ongkara adalah Pranava, yang artinya "terlahir dari Prana”. Prana adalah sebutan lain dari nafas, lebih tepatnya, nafas adalah aspek Prana yang paling kasar. Lalu disebutkan pula dalam Pustaka Jnanasiddhanta, bahwa Ongkara adalah pikiran manusia. Artinya tubuh halus (suksma-sarira) manusia pun adalah Ongkara. Pustaka yang sama juga menyebutkan bahwa Ongkara memiliki tiga personifikasi, yaitu aksara ANG-UNG-MANG, yang ketiganya adalah manas-buddhiahangkara, tiga elemen pembentuk tubuh mental kita (tryantahkarana).

Pandangan tersebut diatas menegaskan bawasannya setiap nafas yang masuk dan keluar melalui pernafasan merupakan Ongkara. Tubuh manusia merupakan Ongkara, begitu pula dalam pernafasan juga bersemayam Ongkara, jadi melalui pengaturan nafas yang baik maka dapat membantu manusia dalam menyeimbangkan antara pikiran, tubuh mental dan tubuh fisik manusia dalam menjalani seluruh aktifitas sehari-hari. Dalam Vijnana Bhairava Tantra dijelaskan dalam sloka 155-156 sebagai berikut.

\section{Sakarena bahir yati hakarena viset punah |}

Hamsahamsety amun mantram jivo japati nityasah \|155\|

Sat satani diva ratrau sahasranyekavimsatih |

Japo devyah samuddistah sulaho durlabho jadiah $\|156\|$

Terjemahan: 
Nafas yang berhembus menghasilkan suara "sah" dan nafas yang dihirup menghasilkan suara "ha". Dengan demikian berarti setiap individu melakukan mantra hamsah. - 155

Siang dan malam mantra hamsah dilakukan sebanyak 21.600 kali oleh setiap individu. Seperti berjapa, orang yang berpengetahuan selalu melafalkan sang dewi di kesehariannya, namun orang bodoh akan menganggapnya ini sulit. -156 (Singh, 2017:306).

Seseorang yang telah maju dalam latihannya, selalu teguh dalam Prana hamsa atau Prana Sakti yang ada pada susumna karena dia telah menyadari hakikat realitas tertinggi. Prana ini terhubung dengan kesadaran individu (aham atau Sang Aku) yang merupakan saripati dari semua mantra, maka dari itu disebut Prana hamsa. Ber-japa dengan mantra ini dengan penuh kesadaran akan terserap kedalamnya dan akan mencapai kekuatan supranatural juga pembebasan (Singh, 2017:307). Mantra hamsah mengandung arti "akulah itu" yang bermakna "Akulah Siva”. Apabila mantra alamiah ini secara sadar diulang terus menerus, maka suaranya akan berubah dari hamsah menjadi so-ham. Hamsah dan so-ham sama-sama bermakna "Akulah Siva"(Singh, 2017:303)

Nafas adalah energi pemberi kehidupan, gerak nafas merupakan indikator kondisi penyeimbang dalam diri seseorang, ketika apana atau tarikan nafas menghasilkan suara "ha"dan jeda nafas menghasilkan suara "m" dan ketika melakukan Prana atau hembusan nafas menghasilkan suara "sah", jika suara-suara tersebut digabungkan menjadi suara "hamsah". Hamsah merupakan nada mantra yang berlangsung secara terus menerus secara otomatis dan alamiah di setiap makhluk hidup di dunia ini. Jika penyebutan mantra hamsah dalam rangkaian proses bernafasnya manusia yang bermakna "Akulah Siva” dimana Siva sebagai realitas tertinggi, sebagai Brahman, maka secara sadar ataupun tidak sadar melalui bernafas telah mengingatkan manusia bahwa dirinya adalah Ongkara, diri ini adalah Brahman, tubuh fisik ini adalah Brahman, tubuh mantal juga merupakan Brahman yang disimbolkan sebagai Ongkara Pranava. Ongkara bersemayam dalam Prana, maka dari itu nafas sebagai wujud Ongkara Pranava memiliki peranan yang cukup signifikan dalam menyeimbangkan pikiran, tubuh dan mental seorang manusia. Nafas sebagai Prana berfungsi sebagai penghubung untuk menciptakan keharmonisan antara pikiran, fisik dan mental seseorang, seperti yang dijelaskan dalam Sing (2017:8) bahwa pemikiran ini telah lama diperdebatkan dalam dunia filsafat dan psikologi barat tentang bagaimana mungkin pikiran yang bersifat psikis dapat mempengaruhi tubuh yang bersifat fisik. 
Menurut filosofi India, antara tubuh dan pikiran memang ada penghubung dan harus terhubung agar tercipta harmonisasi, penghubung itulah yang dinamakan Prana. Prana bukanlah produk pikiran dan bukan pikiran itu sendiri, Prana adalah energi yang sangat halus, tidak kasar seperti energi fisik. Ini dapat dikatakan sebagai bio-energi yang menangkap getaran pikiran dan ditransmisikan menuju saraf dan plekus, begitu juga sebaliknya Prana menangkap dan mentransmisikan getaran tubuh menuju pikiran. Tubuh selalu mengikuti pikiran, dan Prana adalah penghubung keduanya, dengan demikian, dengan mengendalikan pikiran maka Prana juga dapat dikendalikan. Menurut sivagama, Prana bukanlah suatu yang asing dalam mencapai samvit adat kesadaran. Selama proses mencapai kesadaran, kesadaran itu sendiri bersemayam pada Prana, jadi Prana adalah fase kesadaran. Istilah Prana digunakan baik dalam pengertian umum seperti Prana atau PranaSakti yang berarti energi kehidupan. Energi kehidupan ini bersemayam dalam nafas. Prana atau energi kehidupan ini tidak dapat diakses secara langsung karena sifatnya terlalu halus. Tetapi Prana dapat dikendalikan melalui nafas. Prana juga diartikan secara umum hanya sebagai nafas. Tetapi dalam konteks ini, Prana adalah hembusan nafas atau hasil pernafasan, sedangkan tarikan nafas disebut apamana.

Segala bentuk pengalaman material di dunia ini tidak terlepas dari aktifitas manusia dalam bernafas. Prana dalam wujudnya sebagai nafas mampu mengantarkan kehidupan manusia dalam kondisi seimbang baik pikiran, fisik maupun mental. Melalui pengendalian nafas manusia mampu mengendalikan pikiran, dengan mampu mengendalikan pikiran sebagai sumber awal pembentukan karakter seseorang, maka seseorang akan mampu mengendalikan Prana. Pikiran merupakan penentu dan memegang peranan yang utama sebelum seseorang melakukan suatu tindakan berikutnya baik berkata maupun bertingkah laku. Maka dari itu pikiranlah yang akan menentukan kualitas baik atau buruknya kehidupan diri seseorang kedepannya. Pikiran adalah sumber segala apa yang dilakukan oleh seseorang. Dalam sarasamuscaya sloka 80 diuraikan:

Apan ikang manah ngaranya, ya ika witning indrriya, maprawrtti ta ya ring subhaasubhakarma, matangnya ikang manah juga prihen kahrtanya sakareng.

Terjemahanya:

Sebab yang disebut pikiran itu, adalah sumbernya nafsu, ialah yang menggerakkan perbuatan yang baik ataupun yang buruk; oleh karena itu, pikiranlah yang segera patut diusahakan pengekangannya / pengendaliannya (Kadjeng, 1997:70). 
Yudiantara (2016:266) kembali menegaskan bahwa pikiran dan kesadaran manusia mengolah dan bereaksi terhadap sebuah mantra di berbagai level sekaligus. Di tataran pikiran sadar, pikiran mengolah mantra dengan makna dan asosiasinya, artinya pemaknaan terhadap mantra tersebut akan mengarahkan fokus dan konsentrasi anda pada suatu niat (intention) yang anda ingin tuju dan senantiasa membuat fokus anda memperhatikan (attention) apa yang anda inginkan.

Kekuatan pikiran begitu besarnya, hingga dapat menjadi suatu penopang dan penyebab awal dari setiap sikap dan tindakan manusia. Pikiran menjadi medan energi yang mampu pempengaruhi realitas yang ada di dalam diri dan alam lingkungan di sekitarnya. Ketika seseorang memasuki suatu kondisi baik emosional maupun tidak, pikiran dan tubuh akan merespon dan ikut tenggelam dalam situasi dan kondisi tersebut, ketika kesedihan, kemarahan dan bahkan ketakutan menguasai dirinya karena mendengar sebuah kabar buruk, kesadaran normal dalam diri mulai tenggelam dikuasai oleh kondisi perasaan dan pikiran yang tidak menentu karena mendengarkan sebuah kabar buruk, maka dari itu untuk mengembalikan suatu keadaan menjadi normal kembali, normal dalam artian seimbang antara kondisi pikiran, fisik, dan mental, menghela dan menghirup nafas dalam-dalam menjadi salah satu alternatif yang sangat akurat untuk mengembalikan suatu dalam kondisi semula, dengan menghela dan menghirup nafas dalam-dalam, seseorang berarti melepaskan diri dari semua bebanbeban diri dalam kehidupan yang sifatnya sepele yang mampu mempengaruhi kondisi pikiran manusia, dengan mengatur nafas seseorang dapat masuk menuju denyut kesadaran pikiran yang terdalam, sehingga melalui proses bernafas yang merupakan bagian dari proses Prana mampu mengembalikan kesadaran dalam kondisi semula, kondisi seimbang antara pikiran, tubuh fisik dan mental manusia.

Mencapai sebuah keseimbangan dan keharmonisan dalam hidup, maka pikiranlah satu-satunya yang sangat penting untuk dikendalikan melalui nafas, pikiran akan berinteraksi menjadi membaik dan seimbang dengan sebuah mantra, secara tidak sengaja manusia bernafas sesungguhnya sambil mengucapkan sebuah mantra hamsah secara terus menerus yang kemudian dapat mempengaruhi tataran pemikiran manusia menjadi lebih baik, maka dari itu dengan pengendalian pikiran melalui nafas, maka Pranapun dapat dikendalikan, pengendalian Prana berarti pengendalian diri sebagai wujud dari Ongkara. Melalui kesadaran dan pengendalian tersebut maka keseimbangan dan keharmonisan antara pikiran, tubuh fisik dan mental dapat direalisasikan dalam diri. 


\section{Ongkara Pranava, Peta Sekaligus Kendaraan dalam ritual pribadi di dalam diri}

Bernafas sesungguhnya pekerjaan sakral. Bernafas merupakan ritual pribadi di dalam diri sendiri, karena esensinya bernafas merupakan suatu aktifitas untuk menumbuhkan sifat-sifat mulia di dalam diri, dan yang terpenting adalah suatu proses untuk menumbuhkan kesadaran Agung dan menjadi Kesadaran itu sendiri. Salah satu proses ritual diri ini dapat dilakukan melalui jalan meditasi mantra guna mencapai Kesadaran Agung didalam diri, meditasi ini dapat dilakukan dengan melafaklan suatu mantra sebagai nada mantra, yaitu mantra Ongkara, dengan mengatur nafas sambil mengafalkan Ongkara, sehingga Prana dalam tubuh dapat dikendalikan dengan baik. Saat tubuh minim aktifitas maka Prana akan terarah sepenuhnya ke citta, sehingga menyebabkan pikiran berkelana kesan dan kemari, hingga menimbulkan suatu kondisi dan emosi yang tidak menentu. Melakukan meditasi sesaat, mengkondisikan ulang kesadaran dengan mengulang-ulang mantram Ongkara dapat menjadikan suatu langkah yang preventif yang dapat membantu mengembalikan kondisi dan merubah kualitas kehidupan menjadi lebih baik, Ongkara Pranava sebagai wahanan untuk mengharmoniskan seluruh aspek kehidupan dalam diri, juga berfungsi sebagi peta sekaligus kendaraan dalam melaksanakan suatu meditasi. Salah satu meditasi tersebut adalah meditasi tantra.

Meditasi tantra tidak lain adalah meditasi Ongkara. Karena Ongkara adalah tubuh, maka meditasi Ongkara adalah meditasi di (dan dengan) tubuh (Yudiantara, 2019:45). Om juga disebut Pranava, aliran kehidupan yang merupakan the original vibration. Bentuk maskulin Om adalah Tuhan sendiri (Siwa = Omkara Rupa). Sedangkan aspek feminimnya adalah Tara, yakni Dia yang memberikan "taraka"; bagaikan perahu menyebrangkan (tarati) manusia dari lautan samsara (Yudhiantara \& Devi, 2003:25).

Pencapaian pembebasan, terlepas dari ikatan lautan samsara, dapat diraih dengan mengaplikasikan Ongkara Pranava dalam meditasi mantra, dengan cara mengatur pernafasan dan sambil melafalkan mantra Ongkara secara berulang-ulang. Meditasi Ongkara secara khusus dalam sadanga yoga berada pada tahapan ke-enam, yaitu pada dharana yoga. Pada tahapan ini pelaku yoga akan diajarkan untuk memfokuskan perhatian pada suara Ong. Dalam konteks meditasi ini kosentrasi dilakukan dengan suatu objek Ongkara, kosentrasi dilakukan sampai suara Ong melebur menjadi satu 
dengan keheningan. Dijelaskan dalam lontar Sang Hyang Mahajnana 74 tentang peranan Ongkara dalam meditasi sebagai berikut.

Makweh Sang hyang inajaraken, hana omkara ngaranira, sira parahu sabhawanta, ikang sagara kaharan tasikta, sang hyang omkara pwa sira parahwanta, yatanyanhentasan ikang papamagong, hlas pwa datangripada bhatara, lawansayogya kita, hentyakenta parahunta, apan tan anaprayojananta, an huwus lpas, prayojananta, samangkana juga paknaya.

Terjemahannya:

Sangatlah banyak beliau di ajarkan, ada yang di sebut Ongkara, beliau adalah sebagai perahu dalam mengarungi, melintasi lautan yang sangat luas tak bertepi, sang Hyang Ongkaralah sebagai perahunya, yang akan dapat melintasi lautan penderitaan yang luas, maka tidak akan ada halangan engkau datang menuju Bhatara, kemudian sudah sepatutnyalah engkau mengendalikan atau menghentikan perahumu, apabila engkau tidak memiliki tujuannya, jika engkau sudah memiliki tujuan yang pasti maka sepatutnyalah engkau laksanakan.

Pandangan tersebut diatas menjelaskan bawasannya Ongkara sendiri di tempatkan sebagai kendaraan yang akan menyebrangkan kita dari lautan penderitaan di dunia ini. Penderitaan yang diakibtkan dari adanya pengalaman-pengalaman kesadran manusia yang terpaku pada objeknya baik dalam tataran objek material (yang dapat di interpretasikan oleh pengalaman indria) maupun objek mental seperti imajinasi, memori, dan emosi. Karena kesadaran manusia dapat diperoleh melalui pikiran, namun karena sifat pikiran yang bagaikan monyet suka melompat kesana kemari, melompat di berbagai objek tertentu, kadang suka dan kadang merasa duka, kadang berada pada objek masa lalu, kadang melompat ke masa depan hingga berimajinasi pada suatu kondisi yang belum jelas kebenarannya, maka langkah penting dalam upaya tersebut adalah menggantungkan pikiran pada satu objek tertentu yaitu Ongkara Pranava, suara mantra Ong yang dilafalkan sambil mengatur pernafasan dalam bermeditasi guna memfokuskan pikiran pada satu objek tertentu yaitu Ongkara itu sendiri.

Seperti yang dijelaskan dalam Yudiantara (2019:103) bahwa setelah perhatian mulai terpusat. berikutnya adalah dengan mendengungkan Ongkara dalam hati semata. Ikuti dengungan itu dan rasakan diseluruh tubuh. Setelah cukup, dan mantra sudah tidak lagi diucapkan, maka rasa dari getarannya masih akan tetap terasa. Lalu fokus pada rasa itu. Inilah proses meleburkan Ongkara dalam keheningan sebagaimana dikatakan teksteks tradisional. Dari suara terucap, ke dalam hati, ke rasa dan sensasinya saja, sampai kemudian ke "sumber" dari suara tersebut, yaitu Sang Keheningan. Dalam konteks inilah Ongkara menjadi peta sekaligus kendaraan. Dia menjadi pengantar yang membawa kita pada sumber segala sumber sabda, dan saat bertemu dengan Sang 
Sumber itu, maka kesadaran akan mengalami transformasi. Dia tidak lagi mengalami dinamika personal di tubuh, namun melampaui pengalaman tubuh (transpersonal).

Menempatkan Ongkara sebagai objek dalam meditasi, selain sebagi peta dan sekaligus kendaraan yang dapat mengantarkan kita dari keberadaan menuju ketiadaan, menuju sunya, dengan terbiasa mengelola dan melatih kesadaran melalui meditasi Ongkara, maka mantra itu sendiri dapat berperan sebagai peta dan sekaligus kendaraan untuk menjalankan perahu kesadraan diri manusia dari deras dan kompleksnya arus pemikiran manusia, melintasi gelombang pasang surut yang bersumber dari arus gejolak pikiran kita sendiri, maka bukan hanya dapat memperbaiki kualitas kesadaran manusia, bahkan pelaksanaan meditasi Ongkara ini sudah lebih dari cukup untuk membantu mengoptimalkan potensi personal diri manusia dalam menjalani kehidupan sehari hari dan dalam mencapai ajaran catur purushartha, dan bahkan melalui mediatasi ini kesadaran akan mengalami transformasi dari kesadran personal menuju pada kesadaran Agung.

\section{Kesimpulan}

Ongkara Pranava merupakan wujud dari sebuah keharmonisan antara pikiran, tubuh fisik dan tubuh mental manusia dalam menjalani aktifitas kehidupan sehari-hari di dunia ini. Nama lain dari Ongkara adalah Pranava, yang artinya "terlahir dari Prana". Prana adalah sebutan lain dari nafas, lebih tepatnya, nafas adalah aspek Prana yang paling kasar, setiap nafas yang masuk dan keluar melalui pernafasan manusia merupakan Ongkara. Tubuh manusia merupakan Ongkara. Ongkara Pranava memiliki peranan yang cukup signifikan dalam menyeimbangkan pikiran, tubuh dan mental manusia. Dengan bernafas sesungguhnya manusia sedang mengucapkan sebuah mantra hamsah (Akulah Siwa) secara terus menerus yang kemudian dapat mempengaruhi tataran pemikiran manusia menjadi lebih baik, pikiran akan berinteraksi menjadi membaik dan seimbang dengan sebuah mantra, sehingga dengan bernafas, manusia belajar untuk mengendalikan pikiran, dengan pengendalian pikiran maka Prana dalam tubuh dapat dikendalikan pula sehingga secara perlahan antara pikiran, tubuh fisik dan mental dapat diseimbangkan dan menjadi harmonis.

Bernafas merupakan ritual pribadi di dalam diri, bernafas merupakan suatu aktifitas untuk menumbuhkan sifat-sifat mulia di dalam diri, menumbuhkan kesadaran Agung dan menjadi Kesadaran itu sendiri yang dapat diaplikasikan melalui salah satu 
jalan meditasi Ongkara, meditasi ini dilakukan dengan mengatur pernafasan dan sambil melafalkan mantra Ongkara berulang-ulang, mendengungkan Ongkara dalam hati semata, hingga Ongkara tersebut meleburkan dalam keheningan. Omkara dalam hal ini berfungsi sebagai peta dan sekaligus kendaraan yang dapat mengantarkan kita dari keberadaan menuju ketiadaan, menuju sunya, dengan terbiasa mengelola dan melatih kesadaran melalui meditasi Ongkara, maka mantra itu sendiri dapat berperan sebagai peta dan sekaligus kendaraan untuk menjalankan perahu kesadraan diri manusia dari deras dan kompleksnya arus pemikiran manusia, melintasi gelombang pasang surut yang bersumber dari arus gejolak pikiran kita sendiri, maka tidak hanya dapat memperbaiki kualitas kesadaran manusia, juga dapat membantu mengoptimalkan potensi personal diri manusia dalam menjalani kehidupan sehari hari dalam mencapai ajaran catur purushartha, hingga mengantarkan manusia pada kesadaran Agung.

\section{Daftar Pustaka}

Devi, K. Y. (2003). Rahasya pemujaan Sakti Durga Bhairavi Meditasi, Mantra dan Hakekat Devi Dasa Mahawidya. Surabaya: Paramita.

Kadjeng, N. (1997). Sarasamuscaya. Surabaya: Paramita.

Moleong, L. (2001). Metodologi Penelitian Kualitatif. Bandung: PT. Remaja Rosda Karya.

Sadia, D. I. (2009). Wrhaspati Tattwa. Surabaya: Paramita.

Sandika, I. K. (2019). Tantra Ilmu Kuno Nusantara. Banten: Javanika.

Singh, J. (2017). Vijnana Bhairava Tantra Kumpulan 112 Tehnik Meditasi Untuk Mencapai Kesadaran Ilahi. Denpasar: BaliWisdom.

Yudiantara, P. (2016). Sakti Sidhi Ngucap Eksplorasi dan Aplikasi Ilmu Leak Kandapat \& Dasa Aksara Untuk Ilmu Modern. Denpasar: BaliWisdom.

Yudiantara, P. (2018). Meditasi Tantra Warisan Leluhur Nusantara untuk Manusia Modern. Denpasar: BaliWisdom.

Yudiantara, P. (2019). Ilmu Tantra Bali Aktualisasi Ajaran Leluhur Di Jaman Modern. Denpasar: BaliWisdom.

Yudiantara, P. (2019). Ilmu Tantra Bali Memetakan Ajaran Spriritual Para Leluhur. Denpasar: BaliWisdom.

Yudiantara, P. (2019). Ilmu Tantra Bali Teori dan Praktik transformasi Kesadaran. Denpasar: Bali Wisdom. 